\title{
Analysis of Power Loss for Crystalline Silicon Solar Module during the Course of Encapsulation
}

\author{
Hong Yang, ${ }^{1}$ He Wang, ${ }^{1}$ Dingyue Cao, ${ }^{1}$ Dangmin Sun, ${ }^{2}$ and Xiaobao Ju ${ }^{2}$ \\ ${ }^{1}$ Institute of Solar Energy, Xi'an Jiaotong University, Xian 710049, China \\ ${ }^{2}$ Xian Huanghe Photovoltaic Technology Co., Ltd., Xi'an 710065, China \\ Correspondence should be addressed to He Wang; hw69cn@126.com
}

Received 6 January 2015; Revised 11 April 2015; Accepted 15 April 2015

Academic Editor: Elias Stathatos

Copyright (c) 2015 Hong Yang et al. This is an open access article distributed under the Creative Commons Attribution License, which permits unrestricted use, distribution, and reproduction in any medium, provided the original work is properly cited.

\begin{abstract}
During the course of solar module encapsulation, the output power of crystalline silicon solar module is less than the sum of the maximum output power of the constituents because of power loss. So it is very important to investigate the power loss caused by encapsulation materials and module production process. In this paper, the power loss of crystalline silicon solar module is investigated by experiments systematically for the first time. It is found that the power loss is mainly caused by the resistance of ribbon and mismatch of solar cells; the total power loss is as high as 3.93\% for solar module composed of 72 cells $(125 \mathrm{~mm} \times$ $125 \mathrm{~mm}$ ) connected in series. Analyzing and reducing the power losses are beneficial to optimizing encapsulation process for the solar module. The results presented in this study give out a direction to decreasing power loss and optimizing encapsulation process of crystalline silicon solar module.
\end{abstract}

\section{Introduction}

The crystalline silicon solar module is a workhorse for photovoltaic energy in a long time; the reliability of crystalline solar modules is critical to the cost effectiveness and the commercial success of photovoltaics [1-3]. In order to provide mechanical protection, electrical isolation, and chemical protection, the crystalline silicon solar cells are encapsulated as a sandwich structure. When solar cells are encapsulated into solar modules, the output power of crystalline silicon solar module is less than the sum of the maximum output power of the constituents because of optical power loss and electrical power loss [4]. The optical power loss of solar module is caused by tempered glass with a low iron content and the ethylene-vinyl-acetate (EVA) copolymer encapsulants; the electrical power loss is caused by mismatch of solar cells, resistance of ribbon, and resistance of junction box. Some authors ever reported the optical model of crystalline silicon solar module, or reflection loss of module induced by incident angle of light. However, no detailed investigation about power loss caused by solar module encapsulation has been carried out [5-8]. In this paper, the power loss for crystalline silicon solar module during the course of encapsulation is investigated by experiments systematically for the first time. It is found that the power loss is mainly caused by the resistance of ribbon and mismatch of solar cells; the total power loss is as high as $3.93 \%$ for solar module composed by 72 cells $(125 \mathrm{~mm} \times 125 \mathrm{~mm})$ connected in series. The results presented in this study give out a direction to decreasing power loss and optimizing encapsulation process of crystalline silicon solar module.

\section{Experimental Details}

The crystalline silicon solar cells used in this study are $125 \mathrm{~mm} \times 125 \mathrm{~mm}$ single crystalline silicon solar cells. The experimental sequence is shown in Table 1. First, these solar cells are sorted by Berger simulator; after testing and sorting, the tabbing and stringing are carried out by manual welding, respectively, by using a $1.6 \mathrm{~mm}$ width tinned copper ribbon. The crystalline silicon solar module consists of a glass superstrate, crystalline silicon solar cells, different polymer layers, and tinned copper ribbons. The back side of the module is a white TPT (Tedlar/Polyester/Tedlar). These 72 pieces of single 


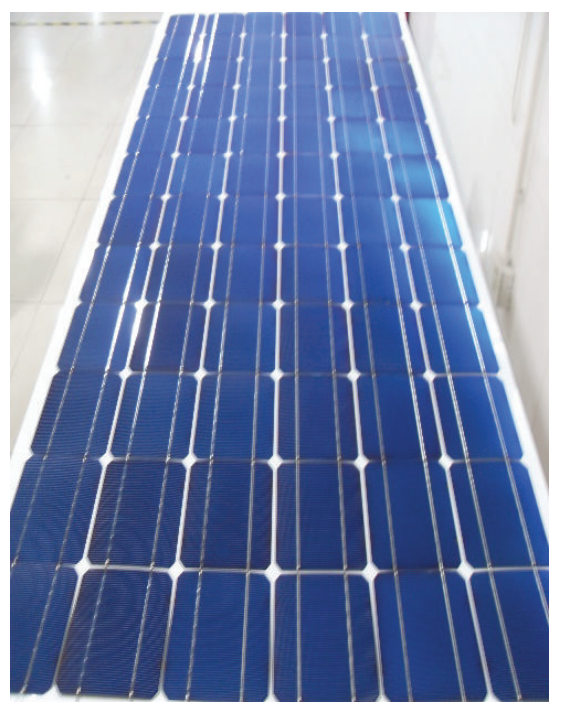

(a) After busing

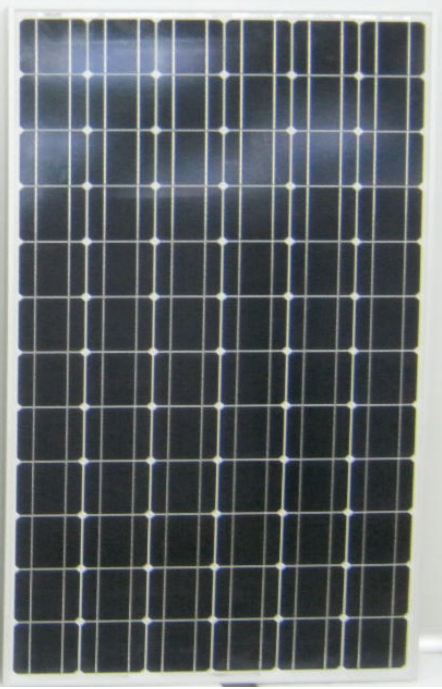

(b) The finished module

FIGURE 1: The solar module after busing and the finished module.

TABLE 1: Experimental sequence.

\begin{tabular}{ll}
\hline Step number & Process description \\
\hline 1 & Cell testing and sorting \\
2 & Cell tabbing \\
3 & Stringing and busing \\
4 & Power testing \\
5 & Layup \\
6 & Lamination \\
7 & Trimming, framing, and junction box \\
8 & Power testing \\
\hline
\end{tabular}

crystalline silicon solar cells are laminated one module in series [9].

Three Schottky diodes are built in junction box. 24 cells are serially connected with a bypass diode across each string. For comparison, the samples are tested after busing and lamination by PASAN's solar simulator $\left(1 \mathrm{~kW} / \mathrm{m}^{2}\right.$ irradiance, $25^{\circ} \mathrm{C}$ module temperature, and AM1.5 global spectrum), respectively. Figure 1 shows the solar module after busing and the finished module.

In this study, CTM (solar cells to solar module) is the power loss of solar module from solar cells to solar module, so CTM is defined as

$$
\mathrm{CTM}=\frac{\sum_{1}^{72} p_{\mathrm{mc}}-P_{\mathrm{mm}}}{\sum_{1}^{72} P_{\mathrm{mc}}} \times 100 \%,
$$

where $\sum_{1}^{72} p_{\mathrm{mc}}$ is the theoretical maximum output power of the 72 solar cells and $P_{\mathrm{mm}}$ is the maximum output of solar module tested by PASAN's solar simulator $\left(1 \mathrm{~kW} / \mathrm{m}^{2}\right.$ irradiance, $25^{\circ} \mathrm{C}$ module temperature, and AM1.5 global spectrum).

\section{Results and Discussion}

3.1. Investigation of Power Loss Caused by Mismatch of Solar Cells and Resistance of Ribbon. The $P_{\mathrm{mm}}$ is the tested maximum output power of solar module after the solar cells are connected, as shown in Figure 1(a). Table 2 gives out a comparison between the theoretical maximum output power of the 72 solar cells and the $P_{\mathrm{mm}}$.

In order to find the reason why the output power of solar module after busing is smaller than the sum of power of solar cells, the open circuit voltage, optimal voltage, the minimum of short circuit current, the minimum of optimal current, and maximum power for solar cells are shown in Table 3; Table 3 also gives out the solar module's parameters after busing.

From Table 3, the open circuit voltage, the short circuit current, and the optimal current have almost no change; the power loss is mainly caused by the change of the optimal voltage before and after busing $[10,11]$.

The power loss in Table 2 includes two parts: one is caused by mismatch of solar cells and the other is caused by resistance of ribbon. The total power loss is $6.32 \mathrm{~W}$ for such solar module.

3.2. Impact of Resistance of Ribbon on Power Loss of Solar Module. The structure of solar module connected by 72 solar cells in series is shown in Figure 2.

The ribbon is made by the tinned copper, the dimension of the interconnected ribbon is $1.6 \mathrm{~mm} \times 0.18 \mathrm{~mm}$, and the dimension of the busing ribbon is $6 \mathrm{~mm} \times 0.2 \mathrm{~mm}$. The resistivity of the tinned copper ribbon is $2.24 \times 10^{-6} \Omega \mathrm{cm}$. The distance between cells is $2 \mathrm{~mm}$; the distance between strings is $3 \mathrm{~mm}$. According to Figure 2, we obtain

$$
R=110.5 \mathrm{~m} \Omega \text {. }
$$


TABLE 2: The power loss caused by mismatch of solar cells and resistance of ribbon.

\begin{tabular}{lccc}
\hline Solar module & $\sum_{1}^{72} p_{\mathrm{mc}}(\mathrm{W})$ & $P_{\mathrm{mm}}$ after busing $(\mathrm{W})$ & Power loss after busing \\
\hline 1 & 198.83 & 192.53 & $3.17 \%$ \\
2 & 198.23 & 191.91 & $3.19 \%$ \\
3 & 199.52 & 193.00 & $3.27 \%$ \\
4 & 199.01 & 192.57 & $3.23 \%$ \\
5 & 198.17 & 191.95 & $3.14 \%$ \\
6 & 198.93 & 192.81 & $3.09 \%$ \\
\hline
\end{tabular}

Test conditions: $1 \mathrm{~kW} / \mathrm{m}^{2}$ irradiance, $25^{\circ} \mathrm{C}$ module temperature, and AM1.5 global spectrum.

TABLE 3: Solar cell's parameters and solar module's parameters after busing.

\begin{tabular}{lcccc}
\hline Cell's parameter & Value $(C)$ & Module's parameter & Value $(M)$ & Value $(M) /$ value $(C)$ \\
\hline$\sum_{1}^{72} V_{\text {oc }}(\mathrm{V})$ & 45.04 & $V_{\mathrm{oc}}(\mathrm{V})$ & 44.85 & $99.58 \%$ \\
$\sum_{1}^{72} V_{m}(\mathrm{~V})$ & 38.01 & $V_{m}(\mathrm{~V})$ & 36.57 & $96.21 \%$ \\
Min. $I_{\mathrm{sc}}(\mathrm{A})$ & 5.53 & $I_{\mathrm{sc}}(\mathrm{A})$ & 5.58 & $100.90 \%$ \\
Min. $I_{m}(\mathrm{~A})$ & 5.25 & $I_{m}(\mathrm{~A})$ & 5.28 & $100.57 \%$ \\
$\sum_{1}^{72} p_{\mathrm{mc}}(\mathrm{W})$ & 198.78 & $P_{\mathrm{mm}}(\mathrm{W})$ & 192.46 & $96.82 \%$ \\
\hline
\end{tabular}

Test conditions: $1 \mathrm{~kW} / \mathrm{m}^{2}$ irradiance, $25^{\circ} \mathrm{C}$ module temperature, and AM1.5 global spectrum.

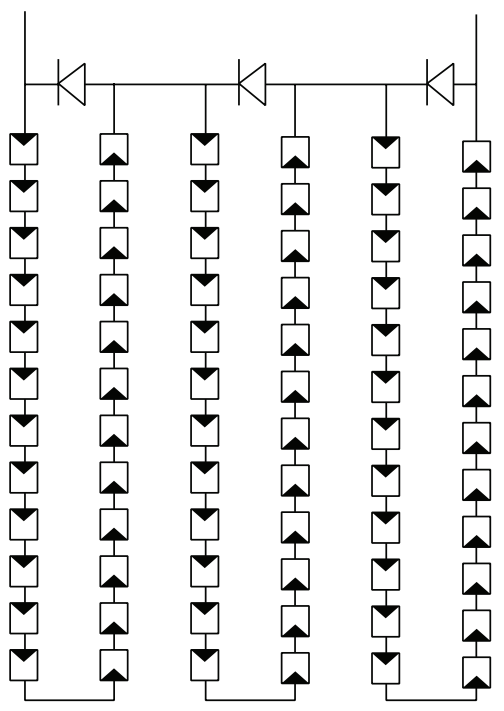

FIGURE 2: Circuit diagram of the solar module with 72 cells.

Because the optimal current of solar module is $5.28 \mathrm{~A}$, the power loss caused by ribbon is $3.08 \mathrm{~W}$. The power loss caused by mismatch of solar cells and resistance of ribbon is $6.32 \mathrm{~W}$, so the power loss caused by mismatch is $3.24 \mathrm{~W}$.

From the above results, it is found that the power loss is mainly caused by the resistance of ribbon. In order to increase the output power of solar module, more thick ribbon is often used, but the thick ribbon could easily cause breakage of solar cells. The relation between the output power of solar module and dimension of ribbon is shown in Table 4.

From Table 4, it is found that the optimal thickness of ribbon is $0.20 \mathrm{~mm}$ for such solar module. When the thickness of ribbon is more than $0.20 \mathrm{~mm}$, the output power of solar module no longer increases. It is found that the more thick ribbon leads to breakage of solar cells frequently; the breakage of solar cells also leads to power loss of solar module [12, 13]. This power loss cancels out the power gain induced by the more thick ribbon.

\subsection{Investigation of Power Loss Caused by Encapsulation} Materials. Table 5 gives out a comparison of the electrical parameters after busing and before lamination.

From Table 5, it is found that the open circuit voltage and the optimal voltage have almost no change; the power loss is mainly caused by the change of the current before and after lamination. The power loss caused by encapsulation materials is $0.80 \mathrm{~W}$ for such solar module.

In fact, the power loss caused by encapsulation materials is more than $0.80 \mathrm{~W}$. Because the TPT is white, some of the light striking regions of the module between cells will be scattered by the back layer and rereflected by the glass superstrate. This can give a boost in the module output. This gain offsets the power loss caused by encapsulation materials [14].

3.4. Investigation of Power Loss Caused by Junction Box. Four kinds of junction box are used in this experiment; Table 6 gives out the power loss caused by different junction box.

$P_{1}$ is the output power of solar module after junction box; $P_{2}$ is the output power of solar module before junction box. From Table 6 , it is found that the mean power loss caused by junction box is $0.585 \mathrm{~W}$.

Figure 3 shows the power loss distribution for crystalline silicon solar module. The power loss caused by mismatch of solar cells and ribbon is $41.51 \%$ and $40.74 \%$, respectively; the power loss caused by encapsulation materials and junction box is $7.5 \%$ and $10.25 \%$. The total CTM is $3.93 \%$ for solar module composed of 72 cells $(125 \mathrm{~mm} \times 125 \mathrm{~mm})$ connected in series. 
TABLE 4: The relationship between the power of solar module and thickness of ribbon.

\begin{tabular}{lccccccc}
\hline Module & $V_{\text {oc }}(\mathrm{V})$ & $I_{\text {sc }}(\mathrm{A})$ & FF $(\%)$ & $P_{m}(\mathrm{~W})$ & $V_{m}(\mathrm{~V})$ & $I_{m}(\mathrm{~A})$ & ${\text { Dimension of ribbon }\left(\mathrm{mm}^{2}\right)}^{2}$ \\
\hline 1 & 44.90 & 5.59 & 75.87 & 190.37 & 36.40 & 5.23 & $1.6 \times 0.14$ \\
2 & 45.01 & 5.60 & 75.88 & 191.26 & 36.43 & 5.25 & $1.6 \times 0.15$ \\
3 & 45.03 & 5.60 & 76.01 & 191.68 & 36.51 & 5.25 & $1.6 \times 0.16$ \\
4 & 45.06 & 5.61 & 76.17 & 192.56 & 36.60 & 5.26 & $1.6 \times 0.17$ \\
5 & 45.08 & 5.62 & 76.21 & 193.09 & 36.64 & 5.27 & $1.6 \times 0.18$ \\
6 & 45.14 & 5.63 & 76.27 & 193.83 & 36.71 & 5.28 & $1.6 \times 0.19$ \\
7 & 45.20 & 5.63 & 76.31 & 194.20 & 36.78 & 5.28 & $1.6 \times 0.20$ \\
8 & 45.19 & 5.64 & 76.19 & 194.19 & 36.71 & 5.29 & $1.6 \times 0.21$ \\
9 & 45.20 & 5.64 & 76.17 & 194.19 & 36.71 & 5.29 & $1.6 \times 0.22$ \\
\hline
\end{tabular}

Test conditions: $1 \mathrm{~kW} / \mathrm{m}^{2}$ irradiance, $25^{\circ} \mathrm{C}$ module temperature, and AM1.5 global spectrum.

TABLE 5: Comparison of the electrical parameters after busing and before lamination.

\begin{tabular}{lcccc}
\hline \multicolumn{2}{c}{ Module's parameter } & \multicolumn{2}{c}{ Module's parameter } \\
After busing & Value $(B)$ & After lamination & Value $(A)$ & $100 \%$ \\
\hline$V_{\mathrm{oc}}(\mathrm{V})$ & 45.04 & $V_{\mathrm{oc}}(\mathrm{V})$ & 45.05 & $100 \%$ \\
$V_{m}(\mathrm{~V})$ & 38.01 & $V_{m}(\mathrm{~V})$ & 38.00 & $99.46 \%$ \\
$I_{\mathrm{sc}}(\mathrm{A})$ & 5.53 & $I_{\mathrm{sc}}(\mathrm{A})$ & 5.50 & $99.24 \%$ \\
$I_{m}(\mathrm{~A})$ & 5.25 & $I_{m}(\mathrm{~A})$ & 5.21 & $99.60 \%$ \\
$P_{m}(\mathrm{~W})$ & 198.78 & $P_{m}(\mathrm{~W})$ & 197.98 & \\
\hline
\end{tabular}

Test conditions: $1 \mathrm{~kW} / \mathrm{m}^{2}$ irradiance, $25^{\circ} \mathrm{C}$ module temperature, and AM1.5 global spectrum.

TABLE 6: The power loss caused by different junction box.

\begin{tabular}{lccccc}
\hline Junction box & Resistance $(\mathrm{m} \Omega)$ & $P_{1}(\mathrm{~W})$ & $P_{2}(\mathrm{~W})$ & $P_{2}-P_{1}(\mathrm{~W})$ & 0.57 \\
\hline Number 1 & 11.19 & 192.41 & 192.98 & 0.53 & $0.289 \%$ \\
Number 2 & 10.41 & 191.80 & 192.33 & 0.65 & $0.269 \%$ \\
Number 3 & 12.28 & 192.56 & 193.21 & $0.329 \%$ \\
Number 4 & 11.35 & 192.50 & 193.09 & 0.59 & $0.299 \%$ \\
\hline
\end{tabular}

Test conditions: $1 \mathrm{~kW} / \mathrm{m}^{2}$ irradiance, $25^{\circ} \mathrm{C}$ module temperature, and AM1.5 global spectrum.

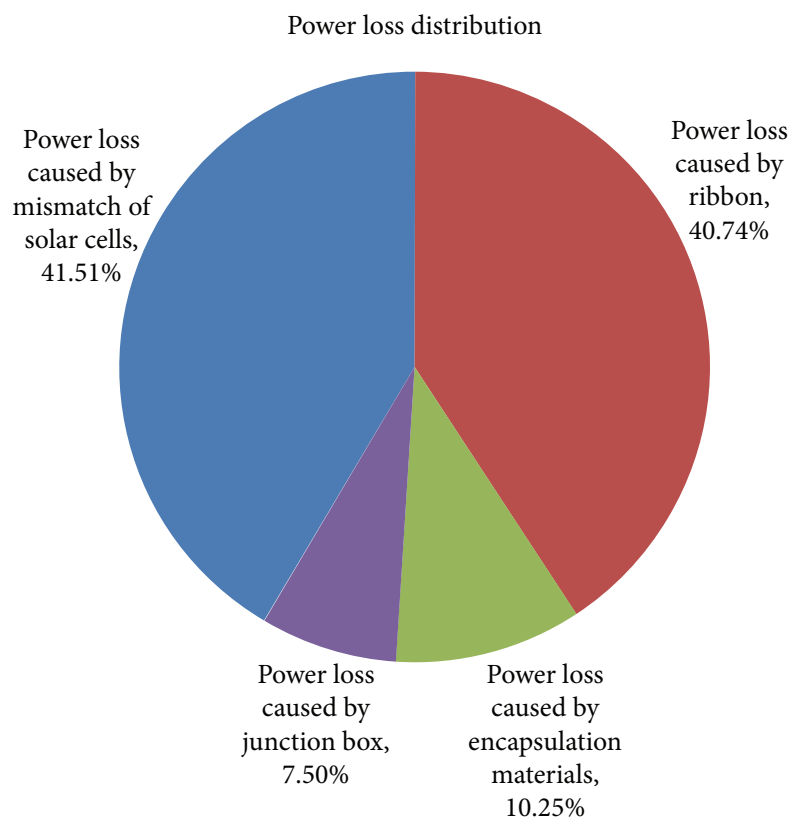

Figure 3: Distribution of the power loss for solar module.

\section{Conclusions}

A systematical investigation about the power loss during the course of solar module encapsulation is carried out in this paper for the first time. The power loss of solar module consists of the optical power loss and the electrical power loss. The optical power loss of solar module is caused by tempered glass with a low iron content and the ethylene-vinyl-acetate (EVA) copolymer encapsulants; the electrical power loss is caused by mismatch of solar cells, resistance of ribbon, and resistance of junction box. It is found that the power loss is mainly caused by the resistance of ribbon and mismatch of solar cells. The total CTM is as high as $3.93 \%$ for solar module composed of 72 cells $(125 \mathrm{~mm} \times 125 \mathrm{~mm})$ connected in series. This conclusion is true for any specifications of crystalline silicon solar modules.

Analyzing and reducing the power losses are beneficial to optimizing encapsulation process for the solar module. The results presented in this study give out a direction to decreasing power loss and optimizing encapsulation process of crystalline silicon solar module. 


\section{Conflict of Interests}

The authors declare that there is no conflict of interests regarding the publication of this paper.

\section{Acknowledgments}

The authors would like to thank the support of the Natural Science Foundation of China (Grant nos. 61274050 and 61376067) and the National 863 Plan (2015AA050301). This study was also supported by the Bureau of Science and Technology (2013k11-02 and CXY1347(6)).

\section{References}

[1] A. Ndiaye, A. Charki, A. Kobi, C. M. F. Kébé, P. A. Ndiaye, and V. Sambou, "Degradations of silicon photovoltaic modules: a literature review," Solar Energy, vol. 96, pp. 140-151, 2013.

[2] T. M. Razykov, C. S. Ferekides, D. Morel, E. Stefanakos, H. S. Ullal, and H. M. Upadhyaya, "Solar photovoltaic electricity: current status and future prospects," Solar Energy, vol. 85, no. 8, pp. 1580-1608, 2011.

[3] H. Yang and H. Wang, "Performance analysis of crystalline silicon solar modules with the same peak power and the different structure," Clean Technologies and Environmental Policy, vol. 13, no. 3, pp. 527-533, 2011.

[4] V. Poulek, D. S. Strebkov, I. S. Persic, and M. Libra, “Towards 50 years lifetime of PV panels laminated with silicone gel technology," Solar Energy, vol. 86, no. 10, pp. 3103-3108, 2012.

[5] P. Maddalena, A. Parretta, P. Tortora, P. Altermatt, and J. Zhao, "Simultaneous optical losses and current measurements in photovoltaic devices at variable angle of the incident light," Solar Energy Materials and Solar Cells, vol. 75, no. 3-4, pp. 397-404, 2003.

[6] T.-H. Jung, H.-E. Song, H.-K. Ahn, and G.-H. Kang, "A mathematical model for cell-to-module conversion considering mismatching solar cells and the resistance of the interconnection ribbon," Solar Energy, vol. 103, pp. 253-262, 2014.

[7] L. L. Bucciarelli Jr., "Power loss in photovoltaic arrays due to mismatch in cell characteristics," Solar Energy, vol. 23, no. 4, pp. 277-288, 1979.

[8] P. Sanchez-Friera, F. Ropero, B. Lalaguna, L. J. Caballero, and J. Alonso, "Power losses in crystalline silicon PV modules due to cell interconnection," in Proceedings of the 23rd European Photovoltaic Solar Energy Conference, pp. 2701-2704, Valencia, Spain, 2008.

[9] R. F. M. Lange, Y. Luo, R. Polo, and J. Zahnd, "The lamination of (multi)crystalline and thin film based photovoltaic modules," Progress in Photovoltaics: Research and Applications, vol. 19, no. 2, pp. 127-133, 2011.

[10] M. C. Alonso-Garcia, N. Martin, F. Chenlo, M. A. Ariza, and P. Sanchez-Friera, "Mismatch analysis in the performance of a photovoltaic module," in Proceedings of the 23rd European Photovoltaic Solar Energy Conference, pp. 2834-2836, Valencia, Spain, 2008.

[11] B. Sadlik, B. Dueperthal, A. Schneider, and L. Rubin, "A quantitative approach to power losses resulting from cell mismatches in solar-modules," in Proceedings of the 22nd European Photovoltaic Solar Energy Conference, pp. 2719-2722, Milan, Italy, 2007.
[12] M. Kntges, I. Kunze, S. Kajari-Schrder, X. Breitenmoser, and B. Bjørneklett, "The risk of power loss in crystalline silicon based photovoltaic modules due to micro-cracks," Solar Energy Materials and Solar Cells, vol. 95, no. 4, pp. 1131-1137, 2011.

[13] H.-H. Hsieh, F.-M. Lin, and S.-P. Yu, "Performance of low seriesresistance interconnections on the polycrystalline solar cells," Solar Energy Materials and Solar Cells, vol. 95, no. 1, pp. 39-44, 2011.

[14] M. B. Koentopp, M. Schütze, D. Buß, and R. Seguin, “Optimized module design: a study of encapsulation losses and the influence of design parameters on module performance," IEEE Journal of Photovoltaics, vol. 3, no. 1, pp. 138-142, 2013. 

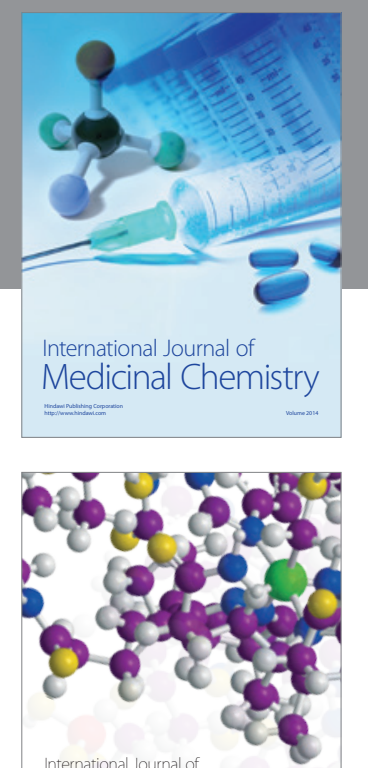

\section{Carbohydrate} Chemistry

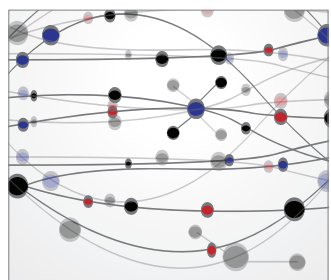

The Scientific World Journal
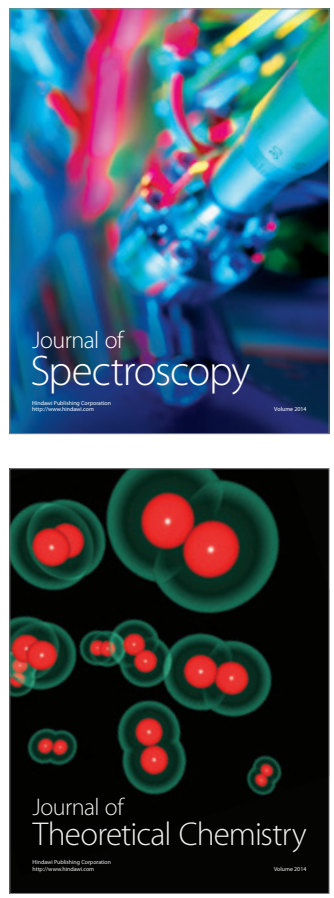
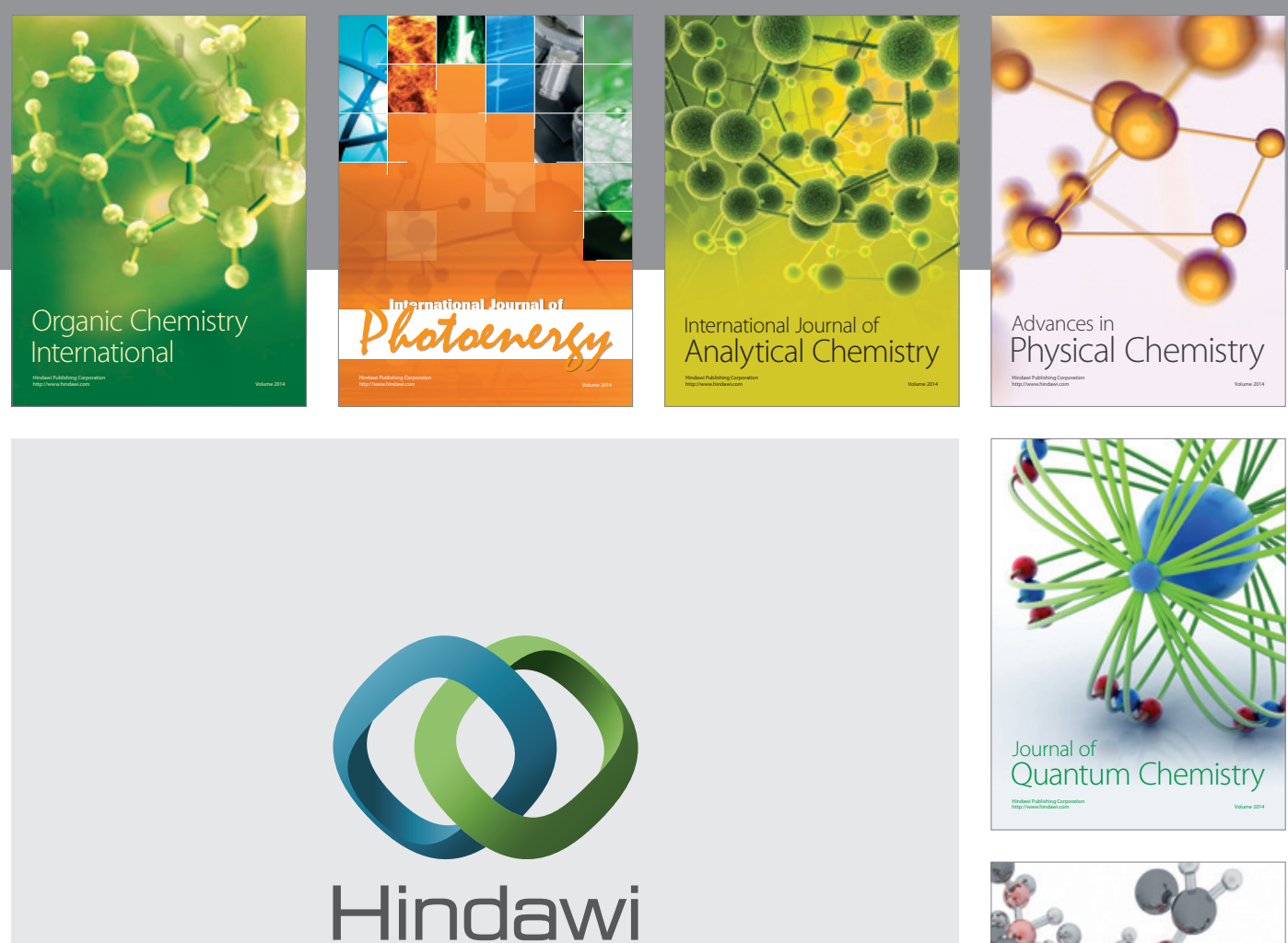

Submit your manuscripts at

http://www.hindawi.com



Analytical Methods

in Chemistry

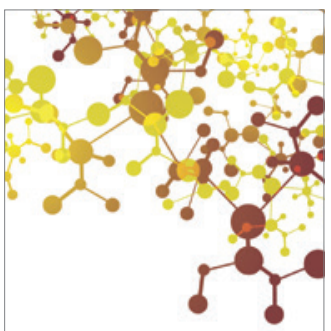

Journal of

Applied Chemistry

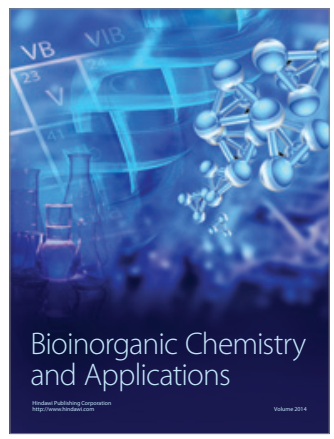

Inorganic Chemistry
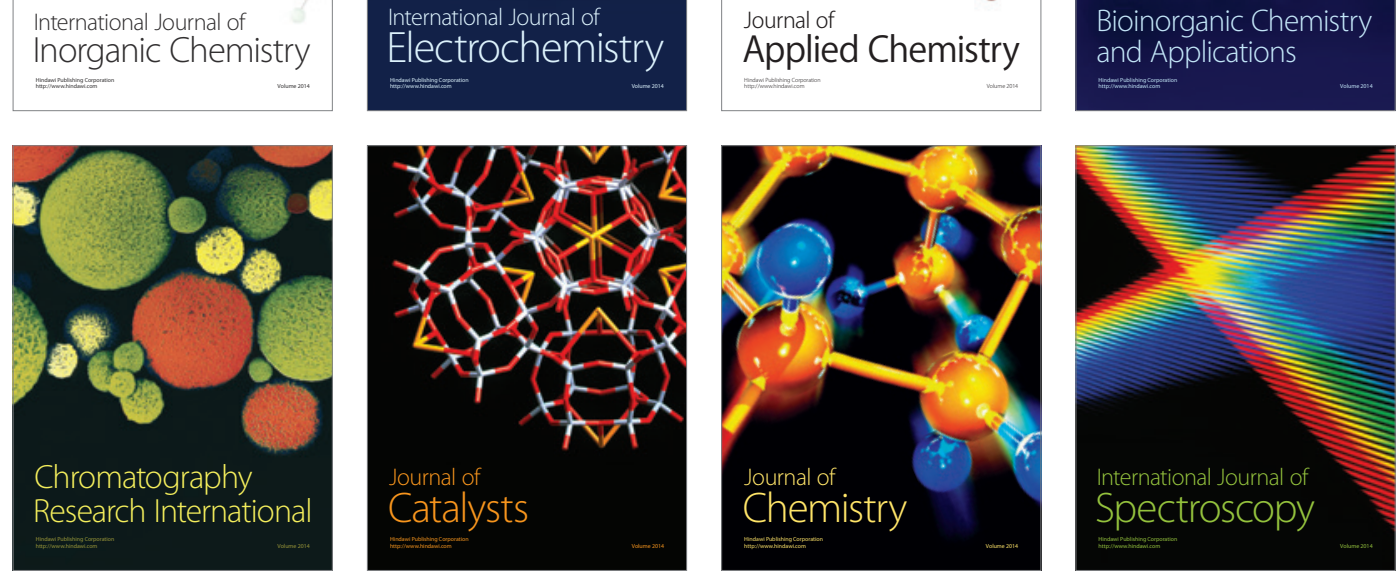